O $\quad$ R I I G I

A $\quad$ R $\quad$ T I I C L $\quad$ L

\title{
Balloon tamponade for postpartum haemorrhage: case series and literature review
}

\author{
Meliza CW Kong 江采華 \\ William WK To 杜榮基
}

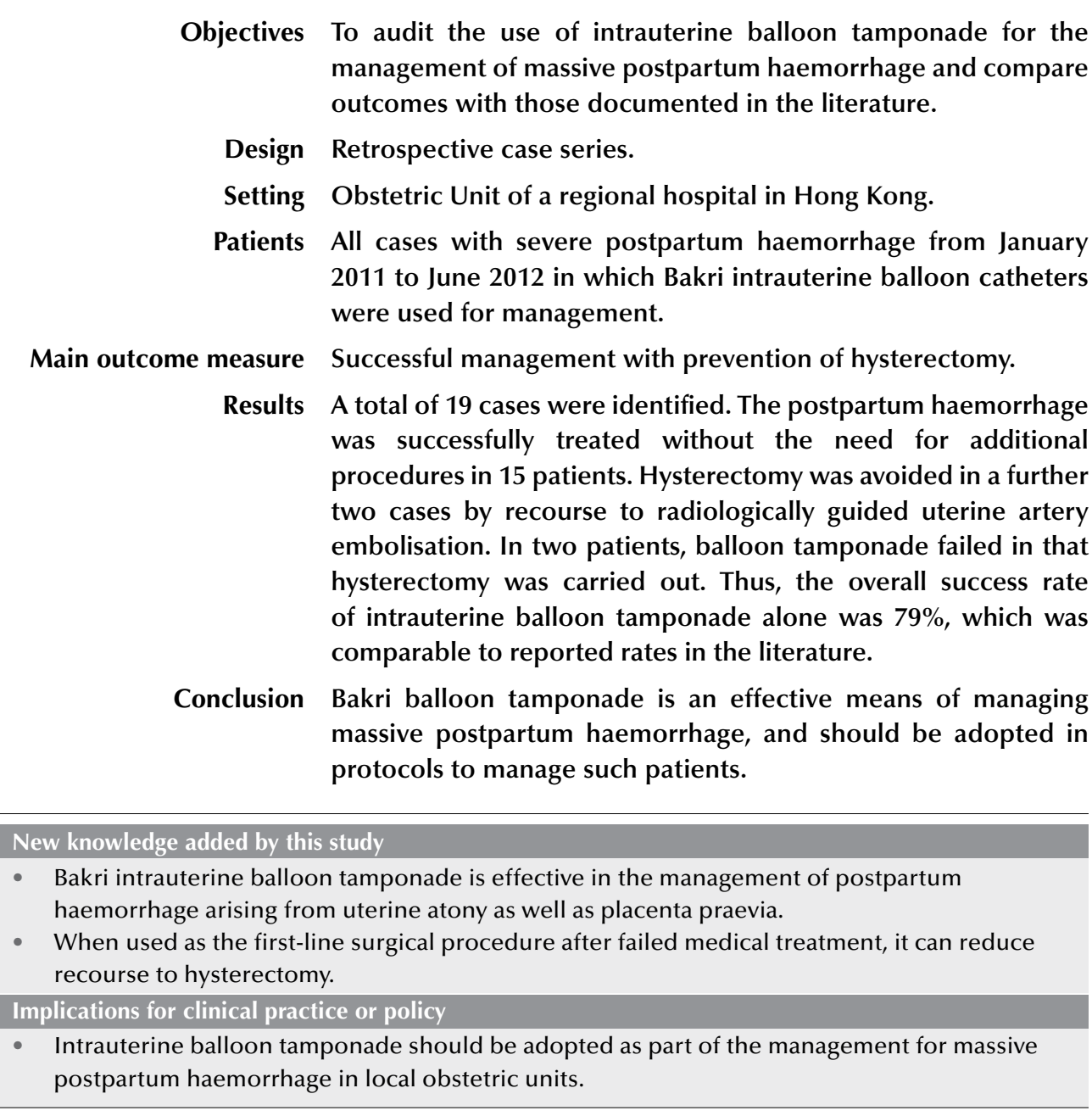

\section{Introduction}

Postpartum haemorrhage (PPH) is defined as an estimated blood loss of more than 500 $\mathrm{mL}$ after delivery and occurs with a frequency of around 5\%. ${ }^{1}$ An additional definition for PPH after caesarean delivery arbitrarily refers to a blood loss of over $1000 \mathrm{~mL} .^{2}$ Firstline treatment options for $\mathrm{PPH}$ include conservative management with uterotonic drugs (oxytocin or prostaglandins); second-line therapy includes uterine packing, external compression with uterine sutures, and selective devascularisation by ligation or embolisation of the uterine artery. ${ }^{3-7}$ Failure of conservative management is often deemed to warrant hysterectomy, which may be associated with further blood loss and additional morbidity. ${ }^{8}$ Although the use of uterotonic drugs and various conservative measures are included in various authoritative protocols, the actual utilisation rates and timing of these procedures vary widely from centre to centre. ${ }^{9}$ Recently, intrauterine balloon tamponade has been quite widely used as a second-line procedure in the management of massive $\mathrm{PPH}$, and has become an integral part of the "HEMOSTASIS" management algorithm widely advocated in the UK.,10 Various types of balloon catheters have been reported in the literature, including the Bakri balloon, the Roush balloon, the SengstakenBlakemore tube, or Foley catheters adapted for intrauterine tamponade. ${ }^{11}$ In Hong Kong, intrauterine balloon tamponade for the management of massive PPH was only introduced as part of obstetric training in the last few years. The current case series describes its use in the management of massive PPH that continued despite medical therapy. All obstetric training and service units in Hong Kong are run under the auspices of the Hong Kong 
Hospital Authority (HA). Accordingly, we set out to retrospectively review a single centre's experience in treating PPH by balloon tamponade. A review of the literature was then conducted to compare our results with those reported worldwide.

\section{Methods}

The Bakri intrauterine balloon catheter (Cook Medical, Bloomington [IN], US) was the only intrauterine balloon device available in our department. A retrospective review of all cases with severe PPH following delivery in our unit during the 18-month period from January 2011 to June 2012 was performed, based on a comprehensive obstetric database currently in use in all HA obstetric units. Specific codings for "obstetric tamponade of the uterus and vagina" and "insertion of therapeutic device into uterus" were identified from the HA clinical management system. Cases of severe PPH with an estimated blood loss exceeding $1.5 \mathrm{~L}$ were also identified from the Labour Ward registry. The case notes of each of these patients were reviewed manually to verify whether intrauterine balloon tamponade techniques had been used in their management. All identified cases where intrauterine balloon tamponade had been used or attempted were then reviewed in detail for the mode of delivery and intrapartum complications. Information was also retrieved about the cause of the $\mathrm{PPH}$, the sequence of treatments, estimated total blood loss, any complications resulting from different therapeutic manoeuvres, and clinical outcomes. The relevant international literature was then reviewed to compare our results with those of others using intrauterine balloon tamponade for the same purpose.

The procedure for insertion of the Bakri balloon was similar to that originally described by the inventor, ${ }^{12}$ though vaginal packing was not routinely performed unless there was evidence of slippage or prolapse of the balloon through the cervix. The distal end of the catheter was taped to the patient's thigh but weights were not used. While ultrasound visualisation of balloon placement was reported in the literature, ${ }^{13}$ this was not considered necessary in our series. When the balloon was inserted during a caesarean section, the distal end of the balloon shaft was passed through the cervical opening with an assistant pulling the end per vagina. The use of a traction suture to keep the balloon in the uterus was not undertaken. ${ }^{14}$ If bleeding was arrested after balloon inflation, the balloon tamponade was continued for 24 hours, after which, the deflation was performed, either in two stages or in a single stage (depending on the attending obstetrician's discretion). All patients had an indwelling Foley catheter to monitor urine output, and broadspectrum antibiotics were used for prophylaxis.

\section{氣囊填塞術治療產後出血：病例系列及文獻回顧}

目的 探討氣囊填塞術治療產後大量出血的使用, 以及與文 獻中的資料作比較。

設計 病例系列回顧。

安排 香港一所分區醫院內的產科部門。

患者 從 2011 年1月至2012年6月期間因產後大量出血而須 使用Bakri子宮填塞球囊導管治療的所有病例。

主要結果測量 避免子宮切除的成功病例。

結果 共研究19個病例。其中15例使用氣囊填塞術成功治療 產後出血而不需額外程序, 2 例亦能進行影像導引下 子宮動脈栓塞術而避免子宮切除術, 另 2 例因氣囊填 塞術失敗須進行子宮切除術。宮內氣囊填塞術的總成 功率為79\%, 可婫美文獻中所記載的成功率。

結論 Bakri氣囊填塞術對於治療產後大量出血非常有效, 應 在有需要的病人中使用。

\section{Results}

In all, there were 8006 deliveries over the review period. The frequency of primary $\mathrm{PPH}$ with an estimated blood loss exceeding $500 \mathrm{~mL}$ was $3.4 \%$ $(n=270)$. The frequency of massive $\mathrm{PPH}$ with an estimated blood loss exceeding $1.5 \mathrm{~L}$ was $0.4 \%(n=35)$. Among the 35 patients with massive $\mathrm{PPH}$, there were 19 patients in whom the Bakri balloon catheter was used. Within the same period, there were six peripartum hysterectomies, two of which involved attempted use of the Bakri balloon catheter and were included in this case series. Of the other 16 (35-19) cases with massive $\mathrm{PPH}$, four were managed with the addition of oxytoxic agents alone, eight had uterine compression sutures (of which six were successful while two failed and underwent hysterectomy), one patient had surgical ligation of the internal iliac artery on one side and the uterine artery on the other side, and another had radiological embolism of the uterine arteries. Two others had placenta accreta not amenable to complete delivery for which balloon tamponade was not considered an option and hysterectomy was performed. These 16 cases that did not involve the use of the balloon catheter in the management were excluded from the subsequent analysis and discussion.

All the identified cases of PPH that involved use of the Bakri balloon catheter failed initial medical management with oxytoxics, including bolus syntometrine, syntocinon bolus and infusion, and intramuscular carboprost injections in $16(84 \%)$ of our 19 cases. Carboprost injections were not used in three patients as the bleeding was considered not due to significant uterine atony. Two patients 
had caesarean sections for major placenta praevia posterior placental bed during caesarean section, and balloon tamponade was used primarily for and transabdominal placement of the balloon was compression of the lower-segment placental bed. In used to achieve tamponade.

the third, brisk bleeding was encountered from the

The mode of delivery was vaginal in $7 / 19(37 \%)$

TABLE I. Clinical and demographic variables in patients treated with Bakri intrauterine balloon catheters

\begin{tabular}{|c|c|c|c|c|c|c|c|c|}
\hline $\begin{array}{l}\text { Patient } \\
\text { No. }\end{array}$ & $\begin{array}{l}\text { Age (years) / } \\
\text { parity }\end{array}$ & $\begin{array}{l}\text { Gestation } \\
\text { (weeks) }\end{array}$ & $\begin{array}{l}\text { Mode of } \\
\text { delivery* }\end{array}$ & Diagnosis $^{\dagger}$ & $\begin{array}{l}\text { Total blood } \\
\text { loss (mL) }\end{array}$ & $\begin{array}{c}\text { Total } \\
\text { transfusion }\end{array}$ & Procedure & Risk factors" \\
\hline 1 & 25 / G2P0 & 39 & LF & Uterine atony & 2200 & 4 u PC/WB & $\begin{array}{l}\mathrm{S}+\mathrm{C} \\
\text { Bakri }\end{array}$ & Polyhydramnios \\
\hline 2 & 39 / G3P1 & 39 & NSD & $\begin{array}{l}\text { Retained placenta; } \\
\text { uterine atony }\end{array}$ & 2000 & $\begin{array}{l}6 \text { u PC/WB } \\
4 \text { u FFP } \\
2 \text { u platelet }\end{array}$ & $\begin{array}{l}\text { MROP } \\
\mathrm{S}+\mathrm{C} \\
\text { Bakri }\end{array}$ & - \\
\hline 3 & 32 / G1P0 & 40 & LSCS & Uterine atony & 1700 & 2 u PC/WB & $\begin{array}{l}\mathrm{S}+\mathrm{C} \\
\text { Bakri }\end{array}$ & - \\
\hline 4 & 35 / G2P1 & 39 & LSCS & Uterine atony & 4000 & $\begin{array}{l}6 \text { u PC/WB } \\
4 \text { u FFP } \\
4 \text { u Platelet }\end{array}$ & $\begin{array}{l}S+C \\
\text { Bakri }\end{array}$ & $\begin{array}{l}\text { Previous CS } \\
\text { Failed induction of } \\
\text { labour }\end{array}$ \\
\hline 5 & 38 / G2P1 & 38 & NSD & Uterine atony & 4600 & $\begin{array}{l}10 \text { u PC/WB } \\
8 \text { u FFP } \\
8 \text { u Platelet }\end{array}$ & $\begin{array}{l}\mathrm{S}+\mathrm{C} \\
\text { Bakri } \\
\text { Total hysterectomy }\end{array}$ & $\begin{array}{l}\text { Cardiac arrest before } \\
\text { laparotomy }\end{array}$ \\
\hline 6 & 40 / G2P1 & 37 & Classical CS & Placenta praevia IV & 2150 & 2 u PC/WB & $\begin{array}{l}\text { S } \\
\text { Bakri x 2ๆ }\end{array}$ & Previous CS \\
\hline 7 & 38 / G3P1 & 35 & LSCS & $\begin{array}{l}\text { Placenta praevia IV; } \\
\text { transverse lie }\end{array}$ & 2000 & 3 u PC/WB & $\begin{array}{l}\mathrm{S}+\mathrm{C} \\
\text { B-Lynch suture } \\
\text { broken } \\
\text { Bakri }\end{array}$ & - \\
\hline 8 & 25 / G1P0 & 36 & LSCS & $\begin{array}{l}\text { Recurrent APH; } \\
\text { uterine atony }\end{array}$ & 6320 & $\begin{array}{l}7 \text { u PC/WB } \\
8 \text { u Platelet } \\
4 \text { u FFP } \\
4 \text { u Cryo-ppt }\end{array}$ & $\begin{array}{l}S+C \\
\text { Bakri } \\
\text { Total hysterectomy }\end{array}$ & Twin \\
\hline 9 & 31 / G1P0 & 38 & LSCS & Uterine atony & 1500 & $1 \mathrm{u} P \mathrm{PC}$ & $\begin{array}{l}\text { S } \\
\text { Bakri }\end{array}$ & - \\
\hline 10 & 31 / G4P1 & 38 & LSCS & Placenta praevia IV & 1800 & $2 \mathrm{u} P C$ & $\begin{array}{l}\text { S } \\
\text { Bakri }\end{array}$ & Previous CS \\
\hline 11 & 38 / G3P0 & 37 & LSCS & Placenta praevia IV & 4000 & $\begin{array}{l}6 \text { u PC/WB } \\
4 \text { u FFP }\end{array}$ & $\begin{array}{l}S+C \\
\text { Bakri } \times 2\end{array}$ & - \\
\hline 12 & 35 / G2P0 & 39 & LSCS & Uterine atony & 1660 & 2 u PC/WB & $\begin{array}{l}\mathrm{S}+\mathrm{C} \\
\text { Bakri }\end{array}$ & - \\
\hline 13 & 37 / G3P1 & 39 & LF & Uterine atony & 2250 & $\begin{array}{l}4 \text { u PC/WB } \\
2 \text { u FFP }\end{array}$ & $\begin{array}{l}\mathrm{S}+\mathrm{C} \\
\text { Bakri }\end{array}$ & - \\
\hline 14 & 32 / G2P1 & 38 & NSD & Uterine atony & 2200 & $\begin{array}{l}4 \text { u PC/WB } \\
4 \text { u FFP }\end{array}$ & $\begin{array}{l}\mathrm{S}+\mathrm{C} \\
\text { Bakri } \\
\text { UAE }\end{array}$ & - \\
\hline 15 & 41 / G3P1 & 38 & NSD & Uterine atony & 3050 & $\begin{array}{l}4 \text { u PC/WB } \\
4 \text { u FFP } \\
4 \text { u Platelet }\end{array}$ & $\begin{array}{l}\mathrm{S}+\mathrm{C} \\
\mathrm{MROP} \\
\text { Bakri }\end{array}$ & GDM \\
\hline 16 & 37 / G2P1 & 39 & LSCS & Uterine atony & 1600 & 2 u PC/WB & $\begin{array}{l}\mathrm{S}+\mathrm{C} \\
\text { Bakri }\end{array}$ & Previous CS \\
\hline 17 & 28 / G3P1 & 40 & VE & Uterine atony & 1500 & 2 u PC/WB & $\begin{array}{l}\mathrm{S}+\mathrm{C} \\
\text { Bakri }\end{array}$ & - \\
\hline 18 & 35 / G2P1 & 39 & LSCS & Uterine atony & 1650 & $\begin{array}{l}2 \text { u PC/WB } \\
2 \text { u FFP }\end{array}$ & $\begin{array}{l}\mathrm{S}+\mathrm{C} \\
\text { Bakri }\end{array}$ & $\begin{array}{l}\text { Compound } \\
\text { presentation }\end{array}$ \\
\hline 19 & 30 / G2P0 & 39 & LSCS & Uterine atony & 1800 & $\begin{array}{l}3 \text { u PC/WB } \\
4 \text { u FFP } \\
2 \text { u Platelet }\end{array}$ & $\begin{array}{l}\mathrm{S}+\mathrm{C} \\
\text { Bakri } \\
\text { UAE }\end{array}$ & Fetal distress \\
\hline
\end{tabular}

* LF denotes low forceps, NSD normal spontaneous delivery, LSCS lower-segment caesarean section, CS caesarean section, and VE vacuum extraction

APH denotes antepartum haemorrhage

FC denotes packed cells, WB whole blood, FFP fresh frozen plasma, and cryo-ppt cryoprecipitate

$\S$ S denotes syntometrine/syntocinon, C carboprost, MROP manual removal of placenta, and UAE uterine artery embolisation

๑ Bakri balloon punctured after first insertion, balloon reinserted vaginally

" CS denotes caesarean section, and GDM gestational diabetes mellitus 
of our series, of which three were normal (2 entailed forceps and 1 was by vacuum extraction). The proportion of caesarean deliveries was 12/19 (63\%).

The most common aetiology for $\mathrm{PPH}$ was uterine atony (15/19), followed by major placenta praevia (4/19). Estimated intra-operative blood losses ranged from $1500 \mathrm{~mL}$ to $6320 \mathrm{~mL}$ (median, $2000 \mathrm{~mL}$ ). All patients received blood product transfusions, and documented disseminated intravascular coagulopathy was present in at least nine $(47 \%)$. One patient had a cardiac arrest shortly after continuous heavy bleeding after Bakri balloon catheter insertion, but was successfully resuscitated and underwent an immediate laparotomy and peripartum hysterectomy. All these patients were admitted to the Intensive Care Unit (ICU) after insertion of the Bakri balloon. Their stays in the ICU ranged from 24 hours to 4 days. In our series of 19 patients, major organ damage was not encountered and there was no other long-term morbidity (Table 1).

In the majority of cases (18/19), the Bakri balloon was the first modality of treatment after medical management; in the remaining patient it was used after failure of compression sutures. In this patient with placenta praevia, B-Lynch sutures were applied followed by closure of the uterine wound, but the sutures broke following ongoing manipulations and a Bakri balloon was therefore inserted vaginally. Additional treatment modalities were carried out in four cases, including two that entailed uterine arterial embolisation and two for whom peripartum hysterectomy was carried out. In all four patients, continuous bleeding exceeded $500 \mathrm{~mL}$ (drained via a catheter), thus prompting further management. The overall success rate in preventing hysterectomy with the Bakri balloon catheter as the only procedure was $15 / 19(79 \%)$, and its success rate in conjunction with other procedures was $17 / 19$ (89\%). Factor VIla was not used in this case series.

There were no major complications arising from the use of the Bakri balloon catheter. In two patients, the balloon was punctured after insertion during the application of haemostatic stitches. Both patients were delivered by caesarean section for major placenta praevia. In one patient, the catheter was inserted transabdominally through the uterine wound. The catheter was partially inflated during uterine wound closure and then more so after closure of the uterine incision. The balloon was punctured while attempting to add more haemostatic sutures around the uterine wound, and so a second balloon catheter was introduced vaginally. In the second case, the Bakri balloon was inserted vaginally after the uterine wound was closed post-caesarean section. Again, the balloon was punctured subsequent to haemostatic sutures to the uterine wound, and a second balloon was reinserted vaginally.

\section{Discussion}

The concept of uterine packing has long been utilised for controlling severe uterine haemorrhage, but Bakri et $\mathrm{al}^{12}$ first proposed using a specifically designed intrauterine balloon catheter, which he did in a series of five women with haemorrhage from low-lying placentae or cervical pregnancies. Subsequently, various types of balloon catheters, including the Foley catheter, ${ }^{15}$ Sengstaken-Blakemore tube, ${ }^{16}$ Rusch balloon, and condom catheters have been adapted for similar clinical scenarios. ${ }^{11}$ At present, the Bakri balloon remains the only balloon product specifically designed for the control of PPH. So far, there are few absolute contra-indications to its use to achieve tamponade. The manufacturer of the Bakri catheter has included uterine anomalies, arterial bleeding, and purulent infection of the genital tract as indications for its use, which have also been adopted in various authoritative guidelines. ${ }^{17}$

While the original Bakri balloon was described for placenta praevia, apparently, such tamponade techniques were also effective in other cases of $\mathrm{PPH}$, such as uterine atony. Using a SengstakenBlakemore balloon catheter as a diagnostic and therapeutic 'tamponade test' in a series of 16 cases, it was shown to effectively stop bleeding in $14(88 \%)$ of patients for the purpose of avoiding surgery. ${ }^{3}$ The authors remarked that this 'diagnostic' test rapidly identifies patients with $\mathrm{PPH}$ that might otherwise warrant a laparotomy. ${ }^{3}$ In another series of 23 cases of $\mathrm{PPH}$ that was unresponsive to medical therapy, ${ }^{18}$ the bleeding was controlled in 18 (90\%) of 20 patients in whom balloon catheters were properly placed. The two others were deemed to require a hysterectomy, despite proper placement. Technical difficulties led to failure of catheter placement in the remaining three. However, when only cases of uterine atony were analysed, the success rate was $100 \%(11 / 11)$.

Other reports have focused on the management of placenta praevia/accreta. One series concentrated on evaluating a protocol for conservative measures to treat placenta praevia/accreta over a period of 15 months. Preventive radiological catheterization of the descending aorta was followed by caesarean delivery, use of Affronti endouterine square haemostatic sutures, and placement of an intrauterine Bakri balloon in conjunction with B-Lynch sutures. A total of nine cases were analysed, and all were successfully treated without resorting to embolisation or hysterectomy. ${ }^{19}$ In another recent series of 37 patients undergoing caesarean section for placenta praevia/ low-lying placenta, it was reported that out of 33 deemed not to require hysterectomy for accreta, 10 $(30 \%)$ warranted a Sengstaken-Blakemore balloon to control bleeding, despite medical treatment. Apparently all of them were successfully treated without additional procedures. ${ }^{20}$ 
TABLE 2. Studies reporting uterine balloon tamponade results with at least five patients

\begin{tabular}{|c|c|c|c|c|c|c|}
\hline Authors & Year & Balloon type & No. of cases & $\begin{array}{c}\text { No. of successful } \\
\text { cases }\end{array}$ & Success rate $(\%)$ & Remarks \\
\hline Goldrath ${ }^{30}$ & 1983 & Foley & 20 & 19 & 95 & - \\
\hline Bakri et al ${ }^{12}$ & 2001 & Bakri & 5 & 5 & 100 & - \\
\hline Condous and Arulkumaran ${ }^{3}$ & 2003 & $\mathrm{SB}^{\star}$ & 16 & 14 & 88 & - \\
\hline Akhter et $\mathrm{al}^{31}$ & 2003 & Condom & 23 & 23 & 100 & - \\
\hline Penney and Brace ${ }^{32}$ & 2003 & Various & 6 & 5 & 83 & - \\
\hline Penney et $\mathrm{al}^{33}$ & 2004 & Various & 30 & 21 & 70 & - \\
\hline Seror et $\mathrm{al}^{16}$ & 2005 & SB & 17 & 12 & 71 & - \\
\hline Keriakos and Mukhopadhyay ${ }^{34}$ & 2006 & Rusch & 8 & 7 & 88 & - \\
\hline Dabelea et $\mathrm{al}^{18}$ & 2007 & Not specified & 24 & 19 & 79 & - \\
\hline Doumouchtsis et al ${ }^{29}$ & 2008 & SB & 27 & 22 & 81 & - \\
\hline Nelson and O'Brien ${ }^{23}$ & 2007 & Bakri & 5 & 5 & 100 & + B-Lynch \\
\hline Vitthala et $\mathrm{al}^{35}$ & 2009 & Bakri & 15 & 12 & 80 & - \\
\hline Albayrak et al ${ }^{15}$ & 2011 & Foley & 15 & 15 & 100 & - \\
\hline Khalil et al ${ }^{14}$ & 2011 & Bakri & 50 & 48 & 96 & - \\
\hline Diemert et al $\left.\right|^{25}$ & 2012 & Bakri & 20 & 18 & 90 & + B-Lynch \\
\hline Arduini et al ${ }^{19}$ & 2010 & Bakri & 9 & 9 & 100 & + B-Lynch \\
\hline Yoong et $\mathrm{a}^{24}$ & 2012 & Bakri & 11 & 11 & 100 & + Hayman \\
\hline \multirow[t]{2}{*}{ Ishii et $\mathrm{al}^{20}$} & 2012 & SB & 10 & 10 & 100 & - \\
\hline & - & - & 311 (Total) & 275 (Total) & 88 (Mean) & - \\
\hline
\end{tabular}

* SB denotes Sengstaken-Blakemore tube

According to the literature, intrauterine balloon tamponade can be deployed concurrently with other conservative techniques. Notably, the successful application of the 'uterine sandwich' using uterine compression sutures in conjunction with the Bakri balloon tamponade has been described in two patients with massive haemorrhage ${ }^{21,22}$ and in a series of five women with PPH due to uterine atony. ${ }^{23}$ A series of 11 cases with placenta praevia or uterine atony using Hayman sutures combined with the Bakri balloon have also been described ${ }^{24}$ with no major complications and a $100 \%$ success rate. Another series of 20 cases was published recently, in which the Bakri balloon was used as the treatment of first choice in 20 cases. ${ }^{25}$ Of these, 12 were successfully managed with the balloon alone but six warranted the balloon and B-Lynch sutures, while two finally had a hysterectomy. ${ }^{25}$

Major complications have been reported following the use of balloon catheters. Thus, caesarean scar dehiscence has been associated with intrauterine balloon tamponade placement after a second-trimester dilatation and evacuation. ${ }^{26}$ Ten weeks following application of uterine compression sutures combined with Rusch intrauterine balloon tamponade, uterine necrosis ensued..$^{27}$ The authors therefore suggested looking out for uterine blanching when applying such balloon/sandwich techniques. Intraluminal pressure was objectively measured while using the Bakri balloon in two patients, and showed that it did not exceed the patient's systolic pressure when tamponade becomes established. ${ }^{28}$ Thus, when used alone, the intrauterine balloon is unlikely to give rise to uterine necrosis, but if used in combination with compression sutures, the risk could well increase.

The efficacy of intrauterine balloon catheters for the treatment for PPH appears similar to other forms of management. In a systematic review of various conservative management modalities for this condition, estimated cumulative outcomes showed success rates of $91 \%$ for arterial embolisation, $84 \%$ for balloon tamponade, $92 \%$ for uterine compression sutures, and $85 \%$ for iliac artery ligation or uterine devascularisation. Nevertheless, the authors commented that balloon tamponade was the least invasive and most rapidly implemented, and that it seemed logical to use it as the first step of management in suitable cases. ${ }^{29}$

At present, there are little direct data to compare and evaluate the efficacy of different second-line conservative management modalities for $\mathrm{PPH}$. Understandably, true randomised controlled trials would be difficult to carry out in such life-threatening clinical scenarios presenting as a dire emergency. A 
fair comparison of the different treatment modalities would also be difficult to carry out, as specific treatments may be indicated in specific situations. For instance, intrauterine balloon tamponade may be particularly indicated for massive PPH after a vaginal delivery, while uterine compression sutures tend to be used (with or without balloon tamponade) after caesarean delivery. Recombinant factor VIla may be more strongly indicated in the presence of disseminated intravascular coagulation when conventional transfusion of blood products fail to reverse the process, while radiological methods for uterine artery embolisation can depend on the availability of expertise of an interventional specialist. It is therefore apparent that the use of these different modalities should be flexible and geared to the aetiology of the $\mathrm{PPH}$ and feasible clinical responses tailored to the condition of the patient concerned during different stages of the emergency.
A literature search on case series of at least five patients describing the use of intrauterine balloon tamponade for the control of PPH going back three decades showed that the mean success rate in preventing hysterectomy was around $88 \%$ (Table 2). ${ }^{3,12,14-16,18-20,23-25,29-35}$ The success rate in our series was consistent with this figure. Apparently, there were no significant differences in success rates when different types of balloon catheters are used. We have no experience of concurrently using the Bakri balloon together with compression sutures, which could further enhance success rates. Nevertheless, the data here show that intrauterine balloon tamponade can be used effectively for the management of massive $\mathrm{PPH}$ in our local setting.

\section{Declaration}

No conflicts of interest were declared by the authors.

\section{References}

1. American College of Obstetricians and Gynecologists. ACOG practice bulletin: clinical practice guidelines for obstetricians gynecologists. Number 76, October 2006: postpartum hemorrhage. Obstet Gynecol 2006;108:103947.

2. Chandraharan E, Arulkumaran S. Surgical aspects of postpartum haemorrhage. Best Pract Res Clin Obstet Gynaecol 2008;22:1089-102. cross ref

3. Condous GS, Arulkumaran S. Medical and conservative surgical management of postpartum hemorrhage. J Obstet Gynaecol Can 2003;25:931-6.

4. B-Lynch C, Coker A, Lawal A, Abu J, Cowen M. The B-Lynch surgical technique for the control of massive postpartum haemorrhage: an alternative to hysterectomy? Five cases reported. Br J Obstet Gynaecol 1997;104:372-5. cross ref

5. Hayman R, Arulkumaran S, Steer PJ. Uterine compression sutures: surgical management of postpartum hemorrhage. Obstet Gynecol 2002;99:502-6. cross ref

6. Doumouchtsis SK, Papageorghiou AT, Arulkumaran S. Systematic review of conservative management of postpartum hemorrhage: what to do when medical treatment fails. Obstet Gynecol Surv 2007;62:540-7. cross ref

7. Postpartum haemorrhage, prevention, management. Greentop guideline no. 52. London: Royal College of Obstetricians and Gynaecologists; 2011.

8. Knight M; UKOSS. Peripartum hysterectomy in the UK; management and outcomes of the associated haemorrhage. BJOG 2007;114:1380-7.

9. Kayem G, Kurinczuk JJ, Alfirevic A, Spark P, Brocklehurst $\mathrm{P}$, Knight M. Specific second-line therapies for postpartum haemorrhage: a national cohort study. BJOG 2011;118:85664. cross ref

10. Varatharajan L, Chandraharan E, Sutton J, LoweV, Arulkumaran $\mathrm{S}$. Outcome of the management of massive postpartum haemorrhage using the algorithm "HEMOSTASIS". Int J Obstet Gynecol 2011;113:152-4. cross ref

11. Georgiou C. Balloon tamponade in the management of postpartum haemorrhage: a review. BJOG 2009;116:748-

\section{7. cross ref}

12. Bakri YN, Amri A, Abdul Jabbar F. Tamponade-balloon for obstetrical bleeding. Int J Obstet Gynecol 2001;74:13942. cross ref

13. Cho Y, Rizvi C, Uppal T, Condous G. Ultrasonographic visualization of balloon placement for uterine tamponade in massive primary postpartum haemorrhage. Ultrasound Obstet Gynecol 2008;32:711-3. cross ref

14. Khalil MI, Al-Dohami H, Aldahish MM. A method to improve the effectiveness of the Bakri balloon for the management of postpartum hemorrhage at cesarean. Int J Gynecol Obstet 2011;115:198-200. cross ref

15. Albayrak M, Ozdemir I, Koc O, Demiraran Y. Postpartum haemorrhage from the lower uterine segment secondary to placenta praevia/accrete: successful conservative management with Foley tamponade. Aust N Z J Obstet Gynaecol 2011;51:377-80. cross ref

16. Seror J, Allouche C, Elhaik S. Use of Sengstaken-Blakemore tube in massive postpartum hemorrhage: a series of 17 cases. Acta Obstet Gynecol Scand 2005;84:660-4.

17. Chapter 89 Balloon tamponade and uterine packing for major PPH. Available from: http://www.health.sa.gov. au/PPG/Default.aspx?PageContentID=2470\&tabid=204. Accessed Apr 2013.

18. Dabelea V, Schultze PM, McDuffie RS Jr. Intrauterine balloon tamponade in the management of postpartum haemorrhage. Am J Perinatol 2007;24:359-64. cross ref

19. Arduini M, Epicoco G, Clerici G, Bottaccioli E, Arena S, Affronti G. B-Lynch suture, intrauterine balloon, and endouterine hemostatic suture for the management of postpartum hemorrhage due to placenta previa accreta. Int J Gynecol Obstet 2010;108:191-3. cross ref

20. Ishii T, Sawada K, Koyama S, et al. Balloon tamponade during cesarean section is useful for severe postpartum hemorrhage due to placenta previa. J Obstet Gynaecol Res 2012;38:102-7. cross ref

21. Danso D, Reginald P. Combined B-Lynch suture with intrauterine balloon catheter triumphs over massive 
postpartum haemorrhage. BJOG 2002;109:963. cross ref

22. Price N, Whitlaw N, B-Lynch C. Application of the B-Lynch brace suture with associated intrauterine balloon catheter for massive hemorrhage due to placenta accreta following a second trimester miscarriage. J Obstet Gynaecol 2006;3:267-8. cross ref

23. Nelson WL, O'Brien JM. The uterine sandwich for persistent uterine atony: combining the B-Lynch compression suture and an intrauterine Bakri balloon. Am J Obstet Gynecol 2007;196:e9-10. cross ref

24. Yoong W, Ridout A, Memtsa M, et al. Application of uterine compression suture in association with intrauterine balloon tamponade (uterine sandwich) for postpartum haemorrhage. Acta Obstet Gynecol Scand 2012;91:147-51. cross ref

25. Diemert A, Ortmyer G, Hollwitz B, et al. The combination of intrauterine balloon tamponade and the B-Lynch procedure for the treatment of severe postpartum haemorrhage. Am J Obstet Gynecol 2012;206:65.e1-4.

26. Soon R, Aeby T, Kaneshiro B. Cesarean scar dehiscence associated with intrauterine balloon tamponade placement after a second trimester dilatation and evacuation. Hawaii Med J 2011;70:137-8.

27. Lodhi W, Golara M, Karangaokar V, Yoong W. Uterine necrosis following application of combined uterine compression suture with intrauterine balloon tamponade. J Obstet Gynaecol 2012;32:30-1. cross ref

28. Georgiou C. Intraluminal pressure readings during the establishment of a positive "tamponade test" in the management of postpartum haemorrhage. BJOG 2009;117:295-303. cross ref

29. Doumouchtsis SK, Papageorghiou AT, Vernier C, Arulkumaran S. Management of postpartum haemorrhage by uterine balloon tamponade: prospective evaluation of effectiveness. Acta Obstet Gynecol Scand 2008;87:84955. cross ref

30. Goldrath MH. Uterine tamponade for the control of acute uterine bleeding. Am J Obstet Gynecol 1983;147:869-72.

31. Akhter S, Begum MR, Kabir Z, Rashid M, Laila TR, Zabeen F. Use of a condom to control massive postpartum haemorrhage. MedGenMed 2003;5:38.

32. Penney G, Brace V. Scottish Confidential Audit of Severe Maternal Morbidity. First annual report 2003. Aberdeen: Scottish Programme for Clinical Effectiveness in Reproductive Health (UK); 2005.

33. Penney G, Adamson L, Kernaghan D. Scottish Confidential Audit of Severe Maternal Morbidity. Second annual report 2004. Aberdeen: Scottish Programme for Clinical Effectiveness in Reproductive Health (UK); 2004.

34. Keriakos R, Mukhopadhyay A. The use of the Rusch balloon for management of severe postpartum haemorrhage. J Obstet Gynaecol 2006;26:335-8. cross ref

35. Vitthala S, Tsoumpou I, Anjum ZK, Aziz NA. Use of Bakri balloon in postpartum haemorrhage: a series of 15 cases. Aust N Z J Obstet Gynaecol 2009;49:191-4. cross ref 